\title{
Freedom and Matter: From Kant to Fichte
}

\section{Aaron Wells}

\section{(2) OpenEdition}

\section{Journals}

Electronic version

URL: http://journals.openedition.org/ref/812

DOI: $10.4000 /$ ref.812

ISSN: 2258-014X

\section{Publisher}

EuroPhilosophie Editions

\section{Electronic reference}

Aaron Wells, «Freedom and Matter: From Kant to Fichte », Revista de Estud(i)os sobre Fichte [Online] 16 | 2018, Online since 01 December 2018, connection on 08 September 2020. URL : http:// journals.openedition.org/ref/812 ; DOI : https://doi.org/10.4000/ref.812

This text was automatically generated on 8 September 2020

(c) EuroPhilosophie 


\title{
Freedom and Matter: From Kant to Fichte
}

\author{
Aaron Wells
}

1 Fichte's mature conception of transcendental freedom is the subject of some controversy. ${ }^{1}$ This paper hopes to shed light on Fichte's later conception by examining his earliest thoughts on the matter. The focus is on three pivotal years of Fichte's development, 1791-93.

2 During these years, Fichte had a number of interlocutors. But Kant was of central importance. Thus I begin with a discussion of Fichte's reflections on how a broadly Kantian conception of transcendental freedom can be manifest in the empirical world. However, Fichte's moves at this point are broadly unsatisfactory, even dogmatic, from a Kantian perspective.

3 However, in several short works from 1792, Fichte's views become significantly more sophisticated. Fichte confronts the worry that neither a metaphysical account of the natural world, nor a mere appeal to 'facts of consciousness,' can be sufficient to establish autonomy in the positive sense.

4 Fichte responds to these worries in two ways. One, relatively well known, is his attempt to prove the existence of practical reason from features of self-consciousness. I focus instead on Fichte's account of moral motivation added to the 1793 second edition of the Attempt at a Critique of all Revelation. There, Fichte sketches an account of pure practical motivation that does not depend on direct appeal to features of self-consciousness, but is more in line with Kant's own appeal to the moral law.

\section{A. 1791: Fichte's Earliest Account of Freedom}

5 Kant's first conception of freedom in the 1760 s was compatibilist. He argues in the New Elucidation free human actions are spontaneous just because they issue from "an inner principle" (New Elucidation 1:402). They are "called forth by...motives of the understanding applied to the will, whereas in the case of brute animals or physicomechanical actions everything is necessitated in conformity with external stimuli and 
impulses..." (NE 1:401). For the early Kant, then, to show that I am free it would suffice to show that my series of representations is causally self-contained - not in interaction with anything "outside." Under the influence of Crusius, Kant quickly came to doubt this hypothesis: for even a lonely monad could be entirely determined in a lawlike way.

Additionally, by the early 1770s, especially in Dreams of a Spirit-Seer, Kant came to worry about any account of the causal interaction between the inner properties and those of spatial experience. That is: if inner properties are really not spatial in any sense, how could they have physical effects? How could my desires, for instance, lead to me raising my arm? Kant does not think efficient causality as such is a deep mystery. The success of Newtonian physics, by his lights, outweighs skeptical doubts about determinism. Yet the example of physics makes the problem of inner properties apparent. The law of gravitation, for instance, makes essential reference to distance. Therefore it presupposes some account of space. The same is true of other kinds of interaction among bodies, such as collision. We have no determinate idea of what nonspatial efficient causality would be like.

7 As is well known, while Kant's transcendental idealism is a theoretical account, its practical import is of central importance. It is intended to make metaphysical room for undetermined agents, which would be transcendentally free. For Kant, lack of external determination is a necessary but not sufficient condition for autonomy.

8 Fichte was a careful if idiosyncratic reader of Kant. Developmentally, Fichte seems to have become concerned with the first question around the time he first read Kant. His sketch of a response in the 1791 Attempt at a Critique of All Revelation appeals to the matter [Materie] of the world of experience - though as I suggest below, Fichte's argument is vulnerable to Kantian objections.

9 He keenly appreciates the connection between revelation (and other divine action) and a Kantian metaphysics of transcendental freedom. Both involve the causal influence of a spontaneous, non-physical being on the deterministic natural order. ${ }^{2}$ For as Fichte defines the concept, revelation would be "an effect produced by God in the sensuous world by means of supernatural causality" (ACR 144; passage omitted in second edition).

10 Yet following Kant, Fichte notes that free finite beings could also "through freedom become a cause in the sensuous world" (ACR 146; passage omitted in second edition). This makes empirical identification of revelation virtually impossible even if one could be certain that it is not due to the laws of spatiotemporal nature. For, to put it simply, one cannot ever be sure that a given experience originates in God, and not in finite freedom. Fichte makes an apparent exception for the pure feeling of respect for the moral law, but this evidently does not conform to typical doctrinal conceptions of revelation.

11 Some of Fichte's remarks seem to suggest a picture on which the laws of nature are up to our own constructive activity. However, while laws do depend on categories and forms of intuition, they are necessary and not freely constructed (ACR 15 / SW V:23; added in second edition). Fichte in fact claims that no object is determinable by absolute spontaneity except the form of our own faculty of desire, which can be freely determined in actual volitions, as "empirical determination[s]" (ACR 16 / SW V:25; added in second edition). 
12 So, even if one grants transcendental freedom to finite agents, the question is then how it can have effects in the natural world. There is only one solution, Fichte suggests:

Their effects in the world of sense...do meet and must not contradict each other, unless either natural cognition [Naturerkenntnis], on the one hand, or the causality of freedom required by practical reason in the world of sense, on the other, is to be impossible. Now the possibility of this agreement of two legislations entirely independent of each other can be conceived in no other way than by their common dependence on a higher legislation that underlies both but which is completely inaccessible to us. If we were able to take its principle as a basis for a world view, then...one and the same effect...appears to us in relation to the world of sense as free according to the moral law, and when attributed to the causality of reason, appears in nature as contingent. But...we are not able to do so... (ACR 88 / SW V:108).

13 Fichte's appeal to a conceivable divine standpoint at this stage departs in a subtle but important way from Kant. For Kant, one need not appeal to any higher legislation to safeguard the theoretical possibility that freedom and spatiotemporal law are not in conflict. The resolution of the Third Antinomy, that is, requires no appeal to a divine or supersensible perspective. Such a perspective instead enters into Kant's projects of moral theology in the third Critique and beyond.

By contrast, Fichte appeals to a divine worldview regarding the mere theoretical possibility of effects of freedom in the natural world.

15 Yet Fichte denies that we can take up the higher standpoint. We can only conceive such a standpoint. That is, we could never occupy a position from which nature and freedom are part of a single legislation. Therefore, Fichte suggests, we must assume

that not all appearances in the world of sense are necessary according to natural laws alone, but rather that many of them are only contingent; and that accordingly we must not explain them all from the laws of nature, but some rather merely according to natural laws. To explain something according to natural laws, however, means to assume the causality of the matter of the effect to be outside nature, but the causality of the form of the effect to be within nature. All appearances in the world of sense must be capable of explanation according to the laws of nature, for otherwise they could never become an object of knowledge. (ACR 88-9; SW V:108)

16 Fichte's suggestion is that scientific laws are formal, leaving some matter undetermined.

17 One way to interpret this is traditional and metaphysical. One can interpret the matter in question as part of the actual material world. In particular, this matter might be thought of as the 'initial conditions' of the actual world (supposing there are any). The same set of natural laws will have very different effects across time depending on the initial conditions.

18 The Fichte of the Attempt certainly seems interested in this sort of picture. He suggests that we can conceive - but not occupy - a God's-eye point of view, from which

nothing is natural and nothing supernatural, nothing...necessary and nothing contingent, nothing is possible and nothing actual. Negatively we can assert this much for certain, obliged by the laws of our thought; but if we wanted to determine the modality of his understanding positively, we would become transcendent. So there can be no question at all concerning how God could conceive of a supernatural effect in the world of sense as possible and how he could actually do it; but rather how we are able to conceive of an appearance as effected by a supernatural causality of God. (ACR 89). 
19 There are a number of Kantian worries about such an approach. First, Fichte might seem to skip over more 'modest' responses to the issue. That is, he takes it that only the idea of something radically beyond a number of theoretically essential concepts can make even the possibility of freedom coherent. Despite Kant's own dabblings with the intuitive intellect late in the third Critique, he does not take any such speculation to be required for conceiving the mere possibility of freedom.

20 Second, for all the ambition of his claims, Fichte gives us little help in using this idea to foster our own speculative perspective on nature and freedom. That is, he confidently claims we can know "how God could conceive" the solution to the relevant problems: but do we know this? And if so, what use is it to us?

21 Third, Fichte ends up seeming committed to many appearances being "only contingent" and not falling under the laws of nature whatsoever. That is, his attempt to vindicate transcendental freedom seems to undermine the explanatory autonomy of science. And I tend to doubt Fichte would let science fall this way (even if it is of far less philosophical interest for him than for Kant or Schelling).

22 Finally, and most importantly, Fichte at most provides what Kant would consider necessary conditions for genuine autonomy. For Kant, autonomy involves a legislative ability to grasp and apply the moral law, as well as an executive capacity to initiate acts in accordance with the moral law. ${ }^{3}$ Yet this seems to involve at least the possibility of self-conscious purposiveness, which a mere metaphysical account of negative freedom cannot provide.

\section{B. 1792: Two Reviews and Fichte's Doubts}

23 In two important reviews published in 1792 - of 'Aenesidemus' and F. H. Gebhard Fichte registers significant doubts with his earliest published account of freedom.

24 With Schulze's publication of the 'Aenesidemus' essay in 1792 Fichte became highly concerned with the effects of the matter [Stoff] of intuition (i.e., sensation) on our theoretical spontaneity, as seen in his review. This became a central preoccupation in the development of Fichte's Wissenschaftslehre. As such, it will be helpful to briefly examine both Schulze's claims and

25 Schulze's 'Aenesidemus' was very influential in renewing interest in theoretical skepticism among the German Idealists, raising the problem of 'givenness' and the unknown causes of our representations. However, Schulze himself never formulates the problem in the terms adopted by Fichte, and it seems fair to say that the questions the review provoked in Fichte far outrun Schulze's actual philosophical claims.

26 Fichte asserts in his review that practical and theoretical philosophy take the "same steps" in different directions; a critical, transcendental philosophy will avoid the pitfalls both of popular philosophical theoretical realism and popular philosophical action theory (EPW 75-6). Still, until its final pages, Fichte's review largely focuses on theoretical issues.

27 Let's begin with the problem as Schulze sees it. In Reinhold, and by extension Kantian philosophy in general, Schulze finds an uncritical acceptance of a "something" which is "the cause and condition of the actuality of representations" (FKtH 108). Here Schulze seems to run together various Kantian concepts, such as the unknown ground of the 
fact of representation in Reinhold and the unknown affecting cause(s) of sensation in Kant. For Schulze, there is merely a classical skeptical problem here. As Schulze correctly notes, the 'somethings' in question cannot be determinately known. How, Schultze then asks, can we be sure that they exist (FKtH 108)?

28 Fichte has a different reading of the problem. He worries that causal affection by an unknown objective ground threatens to make reference and intelligibility more generally depend on an unintelligible brute given. If this really is what Reinhold and Beck think, Fichte reasons, their philosophical projects would be seriously undermined. Where Schulze was basically an empirical skeptic, Fichte's worries concern deep structural features of Kantian philosophy.

29 Fichte's frequent references to matter in this regard draw on some of Kant's technical terminology. Kant claimed that sensation is the matter of intuition. Sensation can mostly be characterized negatively. Form and matter are relative terms. Sensation is the matter of intuition.

30 What of sensation itself? In Kant's technical sense, sensation as such is not 'for' conscious subjects. It is sub-personal, like the models involved in the course of our visual processing. So its laws are not reflectively accessible to us. One positive point Kant does make clear is that sensation is the result of causal affection which is not up to us. ${ }^{4}$

31 'Matter' in fact translates two terms in Fichte's German. When Fichte speaks of the subject-matter of physics and the sciences, or the relative correlate of form, he often uses Materie. With respect to the Kantian sense, where matter is prior to all synthesis, even of space and time, Fichte often uses Stoff. This is the term that usually appears in his technical philosophical works, such as the 1794 Wissenschaftslehre. ${ }^{5}$

32 Kant himself does not explicitly appeal to matter in his account of transcendental freedom. ${ }^{6}$

33 The 'matter' of experience, through which we cognize effects, is intuition. Intuitions are temporal, and subject to causality. So this cannot be construed as a 'gap' in Kantian nature, where freedom finds a way in. In the third Critique and beyond, Kant does develop accounts of matter that may go beyond space and time, for instance in his discussion of genius. The beauty of products of genius can be grounded not in rules, or determinate concepts, but only "that which is merely nature in the subject...namely, the supersensible substrate" (CJ 5:344). Kant maintains that genius is still rooted in what is natural, agential, and even rational - though the nature of this grounding is unknown to us. Still, Kant seems open to the possibility that the grounds of sensation, which are basically unknowable from the empirical perspective, could be effects of supersensible activity.

34 Fichte is aware of relative uses of 'matter' and 'form' in Kant (ACR 15 / SW V:23). He generally uses Materie in this relative sense, and Stoff to refer to what is prior to all synthesis - feeling or sensation - in abstraction from all normative contributions of the understanding. Thus what he has in mind is not the subject-matter of physics, defined in terms of laws. The term simply picks out what we causally ground in abstraction from nomological specification. ${ }^{7}$

35 Let us return to Fichte's 'Aenesidemus' review. He clearly thinks Schulze never appreciated the depth of the problems touched on in his own essay. Epistemologically, Schulze assumes it would make sense for the normativity of the forms of judgment to 
simply result from a causal process as such, absent any further lawlike specification (EPW 68-9). Now, Fichte need not deny causal affection entirely. But a mere causal, informational, or sense-datum account leaves propositional normativity inexplicable. Fichte's difficult example from the review concerns the reason why perceptual experiences must be regarded as actual. Schulze suggested such reasons could simply be given in perceptual experience itself. The idea that the phenomenology of perception involves a distinctive immediacy has enjoyed considerable popularity since Schulze's time. But the mere immediate quality of perception seems quite insufficient - for surely the bee's perceptions are immediate for it as well.

36 Metaphysically, Fichte suggests that a position like Schulze's might as well be Spinozism. For it makes the unknown "not-self" into "the real ground of everything," and we arrive at "Spinoza's fatalism" (H\&L 146). If Kant had assumed causal affection in the way Schulze accused, Fichte suggests in a 1797 letter to Reinhold, Kant would be "in utter contradiction with himself, and this would be obvious to everyone" (EPR, 420). While I can hardly consider Fichte's numerous discussions of this issue here, he usually seems to deny that Kant endorses causal affection in the way Schulze suggests. For example, he explicitly claims in the 'Second Introduction' to the Wissenschaftslehre that on "Kant's view" as well as Fichte's own, knowledge does not proceed from "affection by an object" (to the, H\&L 60).

37 However, from this perspective one might worry about Fichte's claims in the first edition of the Attempt that we must think the entire world as a supernatural effect of God, and its matter as potentially supernatural effects of freedom - even if this is a matter of faith and not objective certainty. For if the form or laws of the world are thought as an effect that is itself lawless or 'supernatural,' some form of Spinozism threatens. Similarly, one might worry that the effects of freedom in the world, even if they are stipulated to be 'ours,' are deeply inscrutable, rather like the "hidden root" of all representation appealed to in Reinhold and J.S. Beck. Yet the 'Aenesidemus' review and the new edition of the Attempt already begin to tackle responses to this problem: that sensation or feeling has a strictly circumscribed role in moral psychology and theoretical justification. Moreover, this role can be transcendentally specified in a way that abstracts from the 'hidden' causal origins of sensation or feeling.

38 I take Fichte himself to allow for an empirical story on which there is causal affection underlying sensation. In the 1794 "Concerning the Concept of the Wissenschaftslehre" Fichte explicitly contrasts that project with that of the empirical sciences. The question of outer determination of mental acts cannot "occur within the Wissenschaftslehre itself" (EPW 120). Nonetheless, this is hardly an unintelligible question. In fact, since it concerns lawlike determination, it must be a matter for "the particular sciences" (EPW 120). This causal story is a mere empirical matter of fact. In questions quid juris, it plays no role. From the transcendental standpoint, causal affection plays no role in experience. This is what licenses strong (and often misleading) Fichtean claims that even feeling is dependent on the activity of the ' $\mathrm{I}$ ': he means that feeling for us requires the activity of the 'I,' and from a transcendental perspective one cannot even cogently speaking of feeling apart from its being for us. ${ }^{8}$

One might object that Kant seemingly does posit a 'real ground' of sensation in certain passages. ${ }^{9}$ In fact, many interpreters of Fichte from Hegel onwards have taken the Fichtean Anstoss to itself be a transcendental real ground - something like the thing in itself, or even a mechanical cause affecting the subject. ${ }^{10}$ More charitable readings of 
both Kant and Fichte are available, however. On Fichte's own interpretation of the Critical Kant, reality is an empirical and 'human' matter for anthropology; the real in sensation can be 'anticipated,' but only by calling attention to features of space and time as such. So the 'matter' of sensation plays no substantive role in Kant's transcendental epistemology. Similarly, Fichte refers to the Anstoss in a highly indeterminate way, even though in each actual empirical case it is determinate 'factive' consciousness.

40 Fichte sometimes casts himself as simply working out and justifying Kant's insights. as he writes to Niethammer in 1793, "whoever shows us how Kant arrived at this substrate without extending the causal law beyond its limits will have understood Kant" (EPW 369). Up to a point, Kant would be entirely in agreement with Fichte's claims, given his denial of any substantive transcendental role for the ground of sensory affection. However, it must be stressed that Fichte sharply breaks with Kant regarding 'empirical' and 'transcendental' questions of freedom. For Fichte, what Kant considered mere empirical spontaneity - whether theoretical or practical - becomes a central question for transcendental philosophy. By contrast, the question of metaphysical transcendental freedom as a causal power, which is at the heart of Kant's transcendental philosophy, in Fichte quickly becomes regarded as a question for the empirical sciences, not philosophy. ${ }^{11}$

41 However, Kantian doubts about such a program might remain: one could worry that Fichte fails to exclude substantial metaphysical threats to our merely negative freedom from external determination. Does this mean Fichte's position is dogmatic, from a Kantian point of view? ${ }^{12}$ It is unclear that Fichte's position need conflict with Kant's; in fact, Fichte may turn away from the metaphysics of transcendental freedom because he took Kant to have said all that was needed on the subject. ${ }^{13}$ It is very possible - if far from certain - that in his last writings Kant himself aimed to revisit the relation between theoretical spontaneity and causal affection..$^{14}$ Kant's project there can be seen not as an uncritical attempt at a priori physics, but as seeking to specify in greater detail the conditions of cognitive activity under which sensation comes to play a justificatory role.

42 But leaving Kant's late work aside, it is worth noting that Fichte addresses such issues - at least to some degree - in his review of Gebhard's On Ethical Goodness as Disinterested Benevolence. ${ }^{15}$ Fichte is largely uninterested in the details of this work, rather viewing it as an occasion for reflection on the Kantian theory of freedom and motivation.

43 Much of Gebhard's work purports to defend Kant against a theory of morality based on a disinterested or benevolent drive, as defended in Adam Smith's Theory of Moral Sentiments. Fichte regards both Smithian moral psychology and Gebhard's responses as crude. However, he takes the discussion to get at a deep threat to the Kantian system.

We are to consider the hypothesis that our motivation towards what is right is a primitive drive which "cannot be derived from something higher, and indeed, from practical reason" (RevG 303). This hypothesis is basically Humean, since it denies pure practical reason any ultimate motivational force. Instead, on this hypothesis our 'actions' are ultimately just the product of a contest of force between drives. Yet we are not directly aware of this context - and perhaps cannot be. Thus it is unsurprising that the later Hume turns away from psychological self-analysis, and towards a descriptive program concerning our practices of praise and blame. ${ }^{16}$ 

Here Fichte sketches such a proof, based on an appeal to the unity of selfconsciousness. This unity must be in some sense unconditioned; yet only pure practical reason could be unconditioned in this sense - or so Fichte argues. This move foreshadows the arguments of his more famous Wissenschaftslehre. ${ }^{18}$ However, we will put such proofs aside here, in order to focus on the sections Fichte added to the second edition of the Attempt. For there, Kant links the problems discussed in two reviews of 1792, but does not directly tackle the question of proving that reason can determine the will.

\section{1793: Fichte's Revised Account of Freedom}

51 Fichte's newly added section purports to provide a theory of the will. Fichte defines volition as the power "to determine oneself to produce a representation with the 
consciousness of one's own activity" (ACR 9 / SW V:16). Volition is the actualization of the faculty of desire. For one can have a desire that does not determine the will.

52 Fichte's definition of volition begins with a distinction between two distinct aspects: "a representation" and "the consciousness of one's own activity." Of course, there is a sense in which the consciousness of one's own activity could be described as a representation. But it is precisely not the sort of representation involved in theoretical belief or cognition.

53 Thus Fichte claims that on the one hand, volition must take place with respect to some representational content, as when I imagine the soup I plan to order later. For Fichte, this content need not be cognitive: even sensation can be an 'objective' aspect of volition in this sense. However, Fichte recognizes that mere theoretical representation of this content seemingly cannot move one to act. ${ }^{19}$

Instead, volition involves an additional, conative aspect, which is not at all manifest in what is representationally given to consciousness. The seeming fact of "consciousness of self-activity," Fichte allows, could simply arise from ignorance of unknown but genuinely determining causes ( $A C R 14$ / SW V:16). That is, consciousness of self-activity in volition may well be deceptive. A plausible way to read the 'deception' is as concerning a gap between the lived experience of choice and spontaneity, and causal facts that would make it possible. While in that case there would be no willing at all, Fichte is so far presupposing that there is a will (ACR 14 / SW V:22).

55 However, the representational material or content already raises a number of philosophical issues. For it could be that one "self-actively produces" such material (ACR 9 / SW V:16). The far more common alternative is seemingly one in which represented object of volition is given from elsewhere, as "presupposed from theoretical philosophy" (ACR 9 / SW V:16).

56 The system of theoretical philosophy in the background here is, unsurprisingly, that of Kant's first Critique. For supposing the object of volition is not spontaneously produced, it will be an empirical object of inner sense. To return to the simple example above, my imagined representation of the soup is not possible from pure concepts and forms of intuition alone. It depends on what has actually been given to one in sensation. ${ }^{20}$

57 Here, Fichte takes up the basic line of questioning of the Gebhard review. The representation in question stands under logical and transcendental laws. But it is not a product of spontaneous action. For the forms of intuition and the categories, by Kant's lights, are simply not up for our spontaneous determination. Instead, they themselves are spontaneous in the much more minimal sense of synthesizing given manifolds of representation. Yet this empirical synthesis - as Kant would be the first to stress - is "applied to...objects with the feeling of necessity," rather than by way of self-conscious representation or autonomy (ACR 15 / SW V:23).

58 As Fichte now stresses, so-called empirical spontaneity is merely an absence of representational determination by sensations or instincts. Yet these non-rational factors might continue to play a crucial role in determining motivation.

59 Nor can its standing under theoretical rules really explain its motivational role, which seemingly can only be referred to a primitive natural drive (albeit one that we are not conscious of). Again, consider my anticipation of the soup that will satisfy my hunger. What is motivationally essential is not the theoretical representation but desire and anticipation of future pleasure. 
60 This need not be a problem for simple natural desires, such as hunger. It does become an issue if the representation in question is that of one's happiest possible life. For however one determines this state of affairs theoretically, its motivational role remains unclear. (To take a broadly Wolffian example, the 'perfection' of a state of affairs does not, seemingly, entail anything about its motivational role for me.) Moreover, it therefore seems that one's final end is merely a naturally determined fact, no different from the way in which our palate is tickled by hunger. That is, Fichte seems to be suggesting that apart from the case of spontaneity, inclinations determine the will in virtue of some future pleasure. This hedonistic view of motivation outside of the pure moral case is also frequently attributed to Kant. ${ }^{21}$

61 Fichte adopts a surprising solution to the motivational problem. For he denies that finite beings like us are ever capable of "pure volition" (ACR 23 / SW V:33) That is, to return to his distinction between the representational object of volition and the conative determination towards it, only a divine being could spontaneously produce both these aspects.

62 Instead, for Fichte, pure practical reason does involve a grasp of the absolutely right. This is what Kant describes as the legislative or objective aspect of autonomy. Indeed, it seems that Fichte here remains deeply Kantian, in that he does not explicate pure practical reason in virtue of features of self-consciousness, but with respect to something like the moral law.

63 Yet since we are empirical beings, such a representation cannot automatically determine us to act, but must be combined with an empirical spring of action. That is, for finite beings like us, legislative autonomy involves spontaneous representational determination. A perfectly rational being would likewise be determined to act in accordance with the moral law; for such a being "no choice, no selection among different determinations" takes place (ACR 22 / SW V:32). Finite beings like us, by contrast, are not fully conatively determined, but are subject to competing impulses, including an impulse of respect for the moral law.

64 Notably, Fichte here does not attempt to prove, on the basis of mere features of selfconsciousness, the existence of a rich positive conception of autonomy. As such, ${ }^{22}$ it is far from clear that Fichte took the problems surrounding autonomy to be easily solved by appealing to the features of a unifying subjectivity.

\section{Primary Works Cited}

65 (Works by Kant are cited using the standard Akademie and A/B paginations; I have followed the translations in the Cambridge edition.)

EPW | Fichte, J. G. (1988). Fichte: Early Philosophical Writings. Breazeale, D. (ed.). Ithaca: Cornell University Press.

GA | Fichte, J.G. (1962ff.). Gesamtausgabe der Bayerischen Akademie der Wissenschaften. Stuttgart-Bad Cannstatt: Frommann-Holzboog.

H\&L / Fichte, J. G. (1970). Fichte: Science of Knowledge. Heath, P. and Lachs, J. (eds.). New York: Appleton-Century-Crofts. 
RevG / Fichte, J.G. (2001). "J.G. Fichte: Review of Friedrich Heinrich Gebhard, On Ethical Goodness as Disinterested Benevolence." Breazeale, D. (tr.). Philosophical Forum 32(4), 297-310.

SoE | Fichte, J.G. (2005). The System of Ethics. Breazeale, D. and Zöller, G. (eds.). Cambridge: Cambridge University Press.

SW | Fichte, J.G. (1971). Fichtes Werke. Fichte, I. H. (ed.). Berlin: De Gruyter.

\section{Secondary Works Cited}

Ameriks, K. (2000). The Fate of Autonomy. Cambridge: Cambridge University Press.

Breazeale, D. (2013). Thinking through the Wissenschaftslehre: themes from Fichte's early philosophy. Oxford: Oxford University Press.

Druet, P. P. (1972). L'«Anstoss» fichtéen: essai d'élucidation d'une métaphore. Revue philosophique de Louvain, 70(7), 384-392.

Emundts, D. (2004). Kants Übergangskonzeption im Opus postumum: zur Rolle des Nachlasswerks für die Grundlegung der empirischen Physik, Berlin: de Gruyter.

Goh, K. (2012). Between Determinism and Indeterminism: The Freedom of Choice in Fichte's Das System der Sittenlehre. European Journal of Philosophy, 23(3), 439-455.

Guéroult, M. (1920). L'antidogmatisme de Kant et de Fichte. Revue de Métaphysique et de Morale, 27(2), 181-224.

Grüne, S. (2013). Kant and the Spontaneity of the Understanding. In Emundts, D. (ed.) Self, World, and Art. Berlin: De Gruyter.

Hall, B. (2016). Fichte and Kant on the Ground of Experience. Contemporary Studies in Kantian Philosophy, 1, 22-43.

Henrich, D. (1982). "Das Problem der Grundlegung der Ethik bei Kant und im spekulativen Idealismus," in: Selbstverhältnisse: Gedanken und Auslegungen zu den Grundlagen der klassischen deutschen Philosophie. Stuttgart: Reclam, 6-56.

Kohl, M. (2015). Kant on Freedom of Empirical Thought. Journal of the History of Philosophy 53(2), 301-326.

Neuhouser, F. (1990). Fichte's Theory of Subjectivity. Cambridge: Cambridge University Press.

Pippin, R. (2000). Fichte's Alleged Subjective, Psychological, One-Sided Idealism, in Sedgwick, S. (ed.), The Reception of Kant's Critical Philosophy: Fichte, Schelling, and Hegel. Cambridge: Cambridge University Press.

Prauss, G. (1983). Kant über Freiheit als Autonomie. Frankfurt a.M: Vittorio Klostermann.

Sellars, W. (1970). “...this I or he or it (the thing) which thinks...” Proceedings of the American Philosophical Association 44, 5-31.

Zöller, G. (2007). From Transcendental Philosophy to Wissenschaftslehre: Fichte's Modification of Kant's Idealism. European Journal of Philosophy, 15(2), 249-269. 


\section{NOTES}

1. For an overview of issues in Fichte's Doctrine of Ethics, see Goh (2012). Henrich (1982) is a classic account of the relationship between Kantian autonomy and the texts of Fichte's earlier Wissenschaftslehre.

2. See Neuhouser $(1990,20)$.

3. Engstrom (1988) calls these objective and subjective autonomy, respectively.

4. Compare Reinhold's claim that the material foundations of his philosophical system is "consciousness as an actual fact" (FKtH 84).

5. Complicating the issue further is Fichte's difficult conception of 'feeling' (Gefühl). Fichte takes note of Kant's distinction, in the third Critique, between sensation and mere feeling. Kant's discussion is itself extremely cryptic, but suggests that sensations are essentially able to be constitutively involved in the intuitive representation of extramental objects. Feelings have an essential subjectivity that precludes this constitutive role. Fichte's very helpful notes on his 1795 Grundriss suggest that a subjective feeling is transformed into an indeterminate quasi-object of sensation through something like synthesis (GA II/4, 360ff.). This synthetic process continues in construing the sensation as having at least minimal determinate properties. Elsewhere Fichte notes that infants have not yet developed their constructive abilities, so they still live in a world of feeling rather than a material world (EPW 202). Elsewhere, Fichte is unfortunately not linguistically consistent regarding feeling/sensation/matter.

6. See CPrR 5:24.

7. See $\mathrm{SoE} 15 \mathrm{ff}$.

8. See e.g. the opening of Fichte's System of Ethics ("reason cannot get outside of itself," SoE 23), and Pippin (2000).

9. See Hall (2016).

10. See Druet (1972) and, for a helpful survey of interpretations, Breazeale (2013).

11. Pippin $(2000,156)$ has rightly stressed the early Fichte's emphasis on "the self-sufficiency or autonomy of...the normative domain itself." While I am broadly in agreement with Pippin's claim, it must be stressed that in ordinary life, as opposed to transcendental philosophy, the normative domain is definitely not self-sufficient in this way. Though the empirical stance is of course a rational undertaking, its objects need not be in anything like the normative domain. Moreover, unlike some of his recent interpreters, Fichte is not committed to anything like the unintelligibility or obvious inconsistency of common-sense or popular-philosophical standpoints.

12. See Ameriks (2000).

13. See Guéroult (1920) and Zöller (2007).

14. See Opus Postumum 22:20-95 and Emundts (2004).

15. See SW VIII:418-26. I follow Breazeale's translation (Fichte (2001)).

16. See e.g. Hume's Principles of Morals, IX.6.

17. This could seem too hasty, given Kant's insistence on the interests even of theoretical reason. However, Fichte might reply that by Kant's own admission, all interest is practical. Thus, it cannot be due to theoretical reason alone. This leaves open whether it is ultimately grounded in practical reason, or in some Smithian/Humean drive.

18. See Henrich (1982). Like many other interpreters, he views the Kant of the second Critique as decisively moving away from any attempt to prove the motivational force of pure reason on the basis of a prior conception of spontaneity (e.g., the spontaneity of theoretical reason). By contrast, Ware (2017) stresses the continuity between the account in the second Critique - with its appeal to a 'fact of reason' - and the earlier deduction in the Groundwork. For that earlier 
argument already depends on a notion of pure practical law, just as in Kant's later appeal to the fact of reason.

19. It might be that in logic, one is determined in some sense by theoretical representations - but it does not seem that this involves the direct determination of the will (as opposed to, e.g., judgment).

20. Kant writes: "Once sensation is given...then through its manifold many an object can be invented in imagination that has no empirical place outside imagination in space and time" (CPR A374; compare B278-9).

21. For a dissenting view, see Reath (2006).

22. Pace Henrich (1982).

\section{ABSTRACTS}

Fichte's mature conception of transcendental freedom is the subject of some controversy. This paper hopes to shed light on Fichte's later conception by examining his earliest thoughts on the matter. The focus is on three pivotal years of Fichte's development between 1791 and 1793: A. 1791: Fichte's Earliest Account of Freedom; B. 1792: Two Reviews and Fichte's Doubts; C. 1793: Fichte's Revised Account of Freedom. The paper begins with a discussion of Fichte's reflections on how a broadly Kantian conception of transcendental freedom can be manifest in the empirical world. Then the paper examines several short works from 1792 in which Fichte's views become significantly more sophisticated. It will be shown that Fichte confronts in these works the worry that neither a metaphysical account of the natural world, nor a mere appeal to 'facts of consciousness,' can be sufficient to establish autonomy in the positive sense. It will be argued that Fichte responds to these worries in two ways. One, relatively well known, is his attempt to prove the existence of practical reason from features of self-consciousness. The paper will focus instead on Fichte's account of moral motivation added to the 1793 second edition of the Attempt at a Critique of all Revelation. There, Fichte sketches an account of pure practical motivation that does not depend on direct appeal to features of self-consciousness, but is more in line with Kant's own appeal to the moral law.

\section{INDEX}

Keywords: transcendental freedom, autonomy, determinism

\section{AUTHOR}

\section{AARON WELLS}

University of Notre Dame 